\title{
Invertebrate Megafauna in the Perdido Fold Belt Polygon, Gulf of Mexico, Mexico
}

\author{
Daniel Torruco ${ }^{1 *}$, Alicia Gonzalez-Solis ${ }^{1}$, Angel Daniel Torruco-Gonzalez ${ }^{2}$ and Juan Carlos Rubio Polania ${ }^{1}$ \\ ${ }^{1}$ Centro de investigacion y de Estudios Avanzados del Instituto Politecnico Nacional Unidad Merida, Mexico \\ ${ }_{2}^{2}$ Universidad Anahuac-Mayab, Carretera Merida-Progreso, Mexico
}

Submission: September 15, 2018; Published: November 08, 2018

Corresponding author: Daniel Torruco, Centro de investigacion y de Estudios Avanzados del Instituto Politecnico Nacional. Unidad Merida. 6Km carretera Antigua a Progreso, CP 97310. MeridaYucatan, Mexico

\begin{abstract}
Four oceanographic campaigns were done in the Perdido Fold Belt zone of the Gulf of Mexico during 2016 and 2017 to generate baseline data on several macrodescriptors to characterize the region and establish existing biological-ecological conditions before hydrocarbon exploitation begins in the area. General megafauna invertebrate data were collected by trawling with a sled net ( $2.4 \mathrm{~m}^{2}$ aperture). Seven Phyla were recorded in 66 trawls in a $274,593 \mathrm{~m}^{2}$ area at depths ranging from 44 to $3609 \mathrm{~m}$. Species richness was 299, abundance was $37,024 \mathrm{org} /$ hectare, and biomass was $305.5 \mathrm{~kg} /$ hectare. Total ecological diversity for invertebrate megafauna in the study area as represented by the Shannon-Wiener index, was 5.35bits/ind.Megafauna in this area of the Gulf is very diverse, with the highest abundances of Phyla and species recorded nearest the coast.
\end{abstract}

\section{Introduction}

General invertebrate megafauna distribution extended from the intertidal zone to the hadal zone [1,2]. Despite their wide distribution, very little data is available on benthic invertebrate megafauna[3].This is mainly due to the methodological challenges of quantitative sampling [4,5], especially morphological differences in the different Phyla in the group, as well as their different life stages, which can occur in very different habitats $[1,6]$. This group is ecologically important because it constitutes the foundation of the vertebrate food chain. In addition, they can modify the characteristics of the sediment in which they are found, thus affecting other smaller groups like macro- and meiofauna [7]. Their distribution is closely linked to aspects such as sedimentation [8], organic matter quantity and quality [9], distance from the coast depthand latitude[8,7,10]. They also exhibit varied ecological relationships, including mutualism, parasitism, symbiosis, and commensalism [11], among others. Benthic invertebrate megafauna communities are some of the most affected by anthropogenic activities (e.g. fisheries, hydrocarbon and gas extraction, mining, waste disposal, etc.) $[12,13]$. Baseline data are therefore essential to differentiate between natural and anthropogenic impacts.Knowledge on these communities in the Gulf of Mexico has largely come from assessments done in the northern Gulf under Unites States jurisdiction. This area has seen intense industrial development since the 1930's, when hydrocarbons were discovered in the coastal areas of Louisiana, Texas, Alabama and Florida
[14]. Identification of hydrocarbon deposits in the Mexican portion of the Gulf in the 1970s triggered intense exploitation and exploration, which accelerated the country's economic development and environmental deterioration (mainly due to industrial waste and spills). Gathering quantitative data on biotic communities distributed in potentially affected zones is vital to developing the basic knowledge needed to create programs designed to protect the presently high biodiversity and prevent and mitigate any possible anthropogenic impacts[15].

Study Area

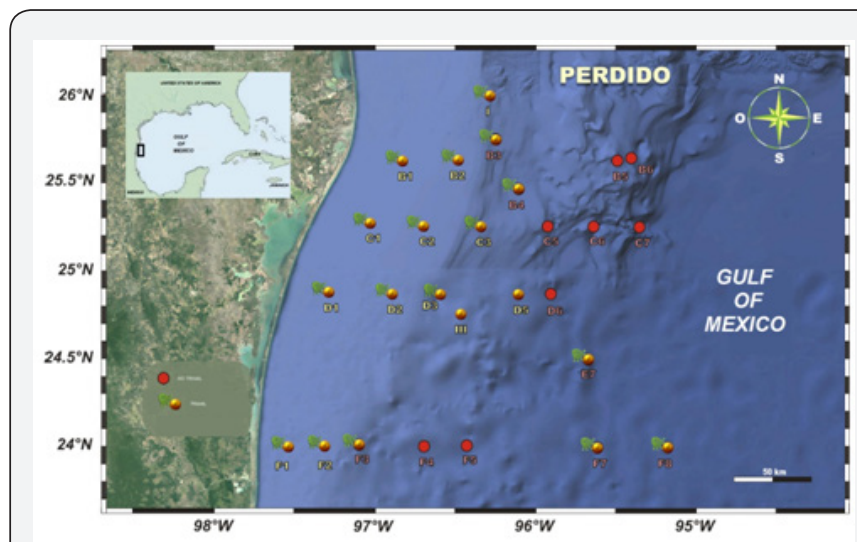

Figure 1: Sampling site locations in the Perdido Fold Belt area off the northeast coast of Mexico. 
The coast immediately west of the Perdido Fold Belt is in the state of Tamaulipas, in northeast Mexico [16]. Regional climate is semiarid, with an average annual temperature of $18^{\circ} \mathrm{C}$ $\left( \pm 14^{\circ} \mathrm{C}\right)$ and average annual rainfall of approximately $800 \mathrm{~mm}$. This precipitation level is intermediate, and the rainfall period is undefined (i.e. precipitation occurs year-round). In the winter, rainfall can be 10 to $36 \%$ higher than the annual average, although this depends on the frequency and humidity of cold fronts. The geology in the northern portion of this area is largely influenced by sedimentation processes [17](Figure 1)

\section{Methods}

Collections were done during four oceanographic campaigns on the vessel Justo Sierra. Samples were collected by trawling with a benthic sled $\left(2.4 \mathrm{~m}^{2}\right.$ aperture). Each trawl (66 in total) lasted for approximately 30 minutes at a speed of 2-3knots. All invertebrates were removed from the captured fauna, weighed and separated by taxonomic group. They were subsequently frozen for transport to the laboratory for identification, counting, measurement and weighing. The data were standardized to org/ hectare to allow production of species-density (abundance and biomass) matrices for each station, and statistical analyses were run to produce graphs of invertebrate megafauna community descriptors. To generate an overall characterization for each collection area, the collected megafauna was also analyzed jointly with all groups by collection campaign. Ecological diversity ( $\left.\mathrm{H}^{\prime}\right)$ was analyzed with the Shannon-Wiener index and evenness (J') with the Pielou index $[18,19]$.

\section{Results}

The four collection campaigns involved a total of 66 trawls and covered an area of $274,593.08 \mathrm{~m}^{2}$. Thirty-eight trawls were done below $500 \mathrm{~m}$, fourteen between 500 and $1000 \mathrm{~m}$ and fourteen at depths greater than $1000 \mathrm{~m}$ (deepest trawl $=3609 \mathrm{~m}$ ) (Table 1).

Table 1: Invertebrate megafauna and collection trawl data for Perdido Fold Belt region.

\begin{tabular}{|c|c|c|c|c|c|}
\hline Parameters & $\begin{array}{l}\text { Perdido_1 } \\
\text { (May-2016) }\end{array}$ & $\begin{array}{c}\text { Perdido_2 } \\
\text { (Sep -2016) }\end{array}$ & $\begin{array}{l}\text { Perdido_3 } \\
\text { (Jun-2017) }\end{array}$ & $\begin{array}{l}\text { Perdido_4 } \\
\text { (Sep-2017) } \\
\end{array}$ & Totals \\
\hline TrawlsTrawls & 15 & 13 & 19 & 19 & 66 \\
\hline Area t Area trawled $\left(\mathrm{m}^{2}\right)$ & 39007.56 & 64316.26 & 83395.56 & 87873.7 & 274593.08 \\
\hline Trawltime (Hrs) & 7.2 & 6 & 9.15 & 9 & 31.35 \\
\hline \multirow{3}{*}{$\begin{array}{l}\text { Dep Depth interval (m) } \\
<1000<\end{array}$} & $<500: 9$ & $<500: 10$ & $<500: 10$ & $<500: 9$ & $<500: 38$ \\
\hline & $500-1000: 3$ & $500-1000: 2$ & $500-1000: 4$ & $500-1000: 5$ & $500-1000: 14$ \\
\hline & $>1000: 3$ & $>1000: 1$ & $>1000: 5$ & $>$ 1000: 5 & > 1000: 14 \\
\hline No. of groups & 6 & 7 & 5 & 7 & 7 \\
\hline Species richness & 112 & 174 & 152 & 114 & 299 \\
\hline Org/hectare & 1457 & 9044 & 9700 & 16823 & 37024 \\
\hline Biomass/hectare (Kg) & 57.27 & 88.5 & 51.1 & 108.71 & 305.58 \\
\hline Diversity (H') (bits/ind) & 4.546 & 4.659 & 4.968 & 4.259 & 5.351 \\
\hline Evenness (J') & 0.706 & 0.652 & 0.71 & 0.615 & 0.68 \\
\hline
\end{tabular}

Seven Phyla were recorded: Arthropoda, Mollusca, Echinodermata, Cnidaria, Annelida, Spongia and Codata. Species richness was generally high, with a total of 299 species, and the highest value was reported on the second campaign. However, the highest abundance $(16,823 \mathrm{org} /$ hectare $)$ and biomass $(108.71 \mathrm{~kg} /$ hectare) were recorded on the fourth campaign (Figure 2A). Diversity was highest on the third campaign (4.968 bits/ind), although values surpassed 4bits/ind on all four campaigns and overall megafauna diversity was $5.35 \mathrm{bits} /$
ind(Figure 2B). Overall evenness was 0.68 and was highest $(>0.7$ ) in campaigns one and three (Figure 2).

Graphs were generated using the recorded parameters for the Perdido Fold Belt invertebrate megafauna community by depth for each campaign. These show trawl positions and the resulting values; circle size is determined by the number of groups, providing a visual indication of how many groups are represented by the macrodescriptors. 

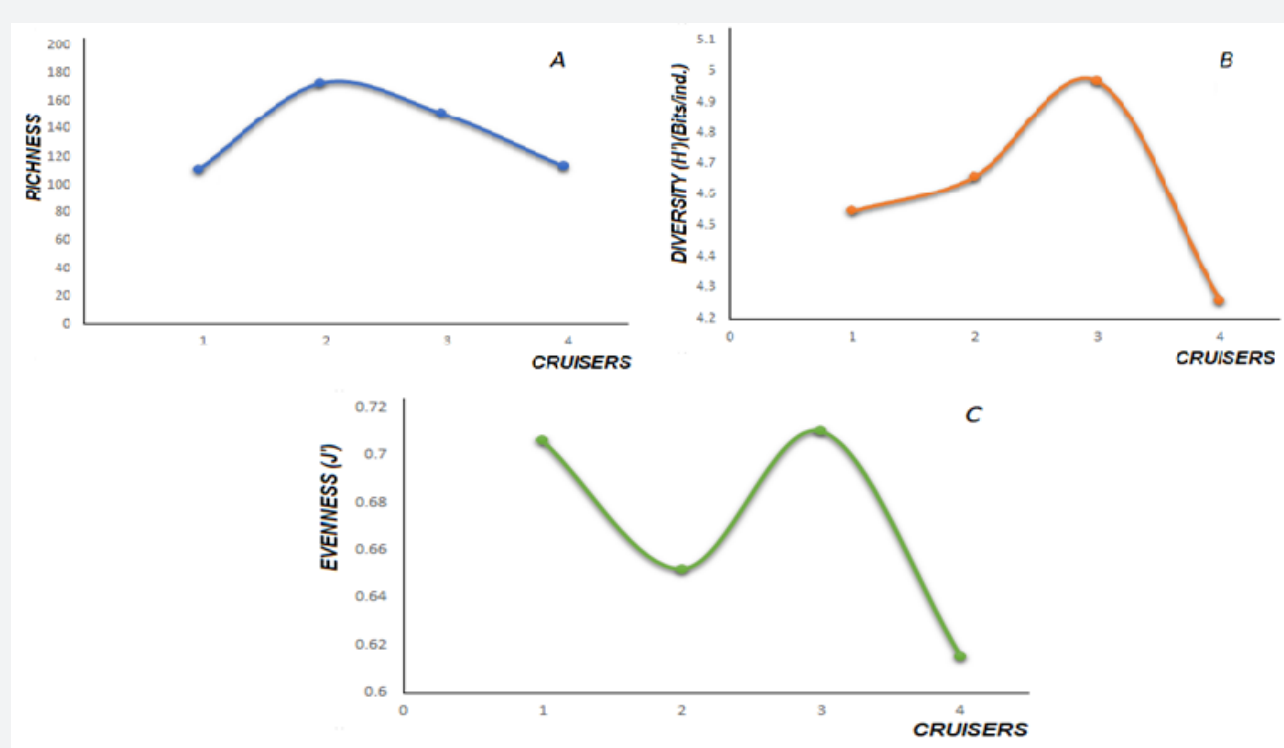

Figure 2: Total ecological macrodescriptor values for invertebrate megafauna collected in the Perdido Fold Belt. A: Species richness showed higher values in the second and third campaigns. B: Ecological diversity had the highest value in the third campaign. C: Evenness was highest in the first and third campaigns.

\section{Phyla}

In the first campaign, the largest number of Phyla were recorded at shallow depths $(<500 \mathrm{~m})$ the smallest number at depths around $500 \mathrm{~m}$, and from two to three phyla were recorded at depths greater than $1000 \mathrm{~m}$ (Figure 3A). The number of Phyla in the second campaign was highest (five groups) at depths near $500 \mathrm{~m}$, lowest (one group) in very shallow locations $(<100 \mathrm{~m})$, and from medium to high ( 3 and 4 groups) at depths greater than $500 \mathrm{~m}$ (Figure 3B). In the third campaign the largest number of phyla (4 groups) was recorded between 80 and $1000 \mathrm{~m}$, and the lowest (one group) at $1500 \mathrm{~m}$, with an increase to three groups at depths greater than $3000 \mathrm{~m}$ (Figure 3C). Variability was high in the fourth campaign, ranging from one to four Phyla in shallow areas and below $1000 \mathrm{~m}$; variability was even higher (1 to 5 groups) at depths greater than $3000 \mathrm{~m}$ (Figure 3D).

\section{Richness}

In the first campaign, species richness exhibited the highest (38 species) and lowest ( 2 species) values at shallow depths $(<500 \mathrm{~m})$, was low at $500 \mathrm{~m}$ ( 4 to 5 species), increased again at $1000 \mathrm{~m}$ (12 species) and then declined at greater depths (8 to 4 species) (Figure 3E). Again, in the second campaign richness was highest (39 species) and lowest (1 species) at shallow depths ( 39 species), and medium (14 to 16 species) at $500 \mathrm{~m}$ and below (Figure $3 \mathrm{~F}$ ). Shallow areas $(<500 \mathrm{~m})$ were also the richest (36 species) in the third campaign, but then richness decreased dramatically from 1000 to $1500 \mathrm{~m}$ (3 species) and varied from four to 22 species in the deepest areas (>3000m) (Figure 3G). In the fourth campaign, richness was high (29 species) in shallow areas, but variable between 500 and $1000 \mathrm{~m}$ ( 9 to 17 species), and below $3000 \mathrm{~m}$ ( 2 to 12 species) (Figure $3 \mathrm{H}$ ).

\section{Abundance}

At shallow depths $(<500 \mathrm{~m})$, abundance in the first campaign was very high (3119org/hectare at the highest), dropped between 500 and $1000 \mathrm{~m}$, increased slightly down to $1500 \mathrm{~m}$ (1152org/hectare) and then decreased drastically (26org/ hectare) (Figure 3I). In the second campaign this parameter was again highest in shallow areas (2301org/hectare), but lowest at locations near $1000 \mathrm{~m}$ (51org/hectare) (Figure3J). Abundance was highest in the third campaign at $45 \mathrm{~m}$ (2129org/hectare), and lowest at $1000 \mathrm{~m}$ (9org/hectare), with a wide interval 51 to 556 org/hectare recorded in areas deeper than 3000m (Figure $3 \mathrm{~K})$. Finally, in the fourth campaign abundance was highest in very shallow areas $(<100 \mathrm{~m})$, ranged from 2 to $777 \mathrm{org} /$ hectare between 500 and $1000 \mathrm{~m}$, and from 18 to $182 \mathrm{org} /$ hectare in deep areas (Figure 3L).

\section{Biomass}

Biomass in the first campaign followed a pattern like its abundance, with high levels at depths less than $500 \mathrm{~m}(12.2 \mathrm{~kg} /$ hectare was highest) decreasing biomass to $500 \mathrm{~m}(0.9 \mathrm{~kg} /$ hectare), followed by a slight increase to $1000 \mathrm{~m}(1 \mathrm{~kg} /$ hectare $)$ and a drastic decrease at depths greater than $1500 \mathrm{~m}(0.4-$ $0.02 \mathrm{~kg} /$ hectare) (Figure $3 \mathrm{M}$ ). In the second campaign, biomass was highest $(40.2 \mathrm{~kg} /$ hectare $)$ in very shallow areas $(<100 \mathrm{~m})$, and lowest near $1000 \mathrm{~m}$ (200gr/hectare) (Figure 3N). In contrast, this parameter was highest in the third campaign at $3200 \mathrm{~m}(10.54 \mathrm{~kg} /$ hectare) and lowest at $1000 \mathrm{~m}$ (10gr/hectare) (Figure 30). The fourth campaign had biomass values consistent with its abundance, the highest biomasses being at depths less than $100 \mathrm{~m}$, low values between 500 and $1000 \mathrm{~m}$ and very low values in deeper areas $(>3000 \mathrm{~m})$ (Figure 3 ). 


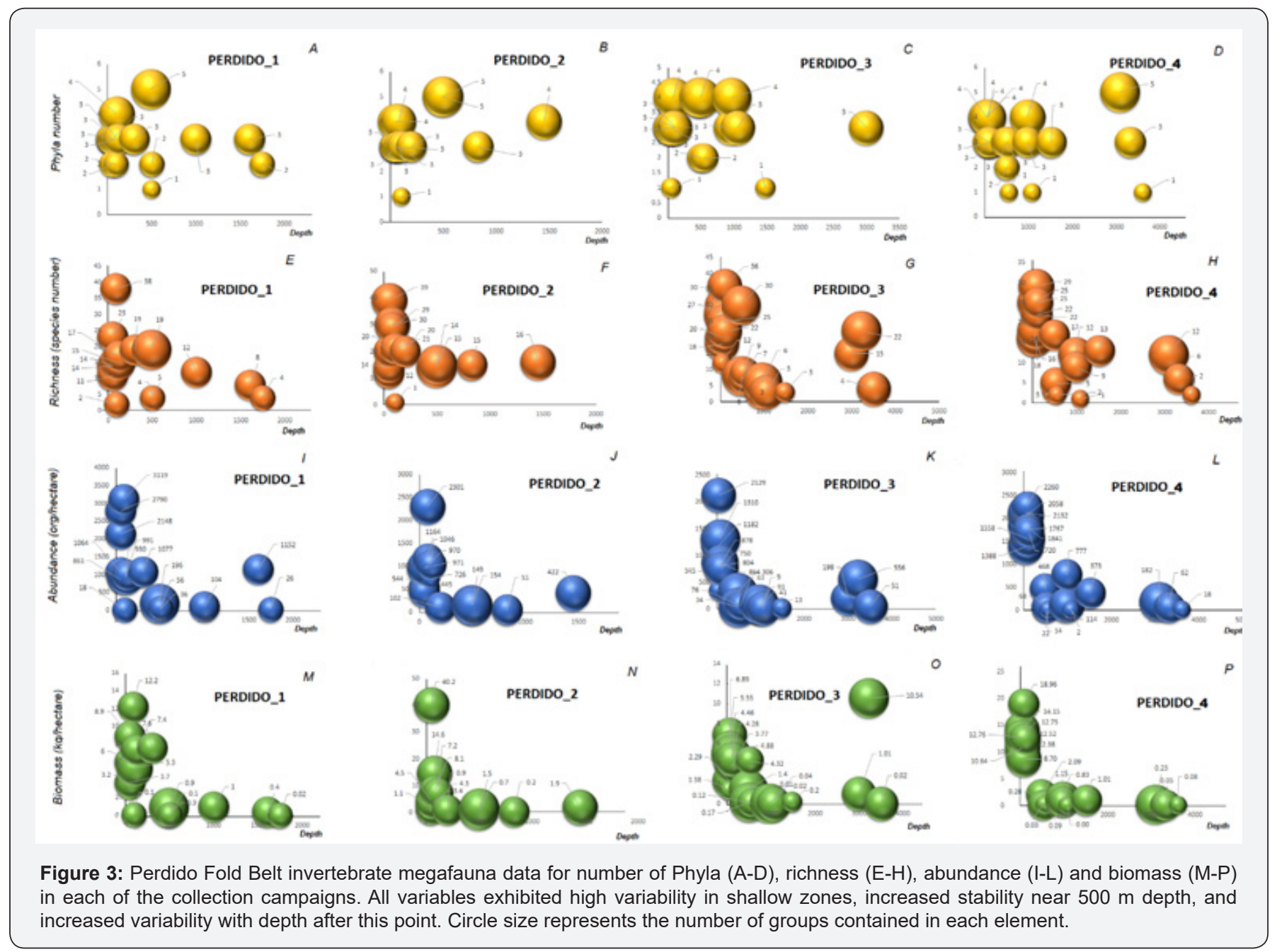

\section{Discussion}

The Perdido Fold Belt may hold enormous oil reserves but extracting the resource will prove difficult since the water column ranges from 2600 to $>3000 \mathrm{~m}$ in depth. The corresponding technological and financial challenges have yet to be overcome.It is likely to be exploited eventually, and it is vital to have a comprehensive record of its biota before intensive hydrocarbon extraction begins. Currently available data on megafauna from the northern Gulf indicates from four to six times more invertebrate species than vertebrates at all depths [3].Of the seven recorded Phyla (Artropoda, Mollusca, Echinodermata, Cnidaria, Annelida, Spongia and Codata) the first three were diverse and abundant while the latter four were sporadic and not very diverse. This is consistent with previous reports for the Gulf of Mexico [3,20]. Overall the data suggest a series of conclusions.Variability was highest in the sampled shallow areas $(<100 \mathrm{~m})$, which was where the highest values for all the parameters were recorded; however, it was also here that the lowest values were recorded. In the 500 to $1000 \mathrm{~m}$ depth zone values began to decrease, a trend which sharpened with depth. However, deeper areas produced unexpectedly high values, some comparable to the shallow area data in terms of richness and abundance.

The approximate coincidence between invertebrate megafauna abundance and biomass in the study area implies that the shallow zones harbored small but abundant organisms, whereas deeper zones contained larger (i.e. heavier) organisms with variable abundance; this is comparable variability in parameter values reported by Murawski et al.[21]for the fish component. Environmental conditions are more stable at greater depths than in shallow and coastal environments[22]. It could be expected therefore that biodiversity among deep sea invertebrate megafauna would be lower and that biotic variables such as competitive exclusion, resource division and predation would be essential factors defining benthic community structure and functioning[23]. However, the present data indicate wide variability in this zone.The dominance of crustaceans and mollusks observed in the present data is like previous reports [24,25]. The species identified have broad adaptive capacities and their dominance may be regulated by the trophic spectrum[24,26]. Several authors (Smith and Hamilton 1983, Lessard-Pilon 2010) propose that marine communities exhibit 
significant variations in local species richness in response to oceanic transport processes and more local variation within sites. In the present study, positional effects on local species richness were also modified by a variety of other, yet unidentified, variables.Some of the causal mechanisms behind the observed patterns may be linked to the patchy bottom in the study region.

Study of the relationship between the number of species occurring in a habitat and the number present in a group of large regions dates toTerborgh\&Faaborg[27]. Following ecological theory, they proposed that the number of species occurring within habitats, especially in the tropics, is controlled by the local environment (physical factors and biological interactions). In contrast, the number of species in a region is influenced by evolutionary history and the regional scale of physical processes [28]. In the Perdido Fold Belt, it appears that, rather than evolutionary dynamics, it is the physical processes and factors that control this parameter in the invertebrate megafauna[29]. Community structure and the processes influencing biodiversity in the study area clearly respond to the dominance of mollusks, crustaceans and echinoderms, which alternates between species from these three groups. Abundance and biomass values differed little between campaigns and were mainly due to the number of trawls done in each[30]. The differences found in the second campaign were more likely a reflection of the time of year (September), which could manifest as differences in the life stages and body size of collected individuals; the fourth campaign was done at the same time of year, but the data it generated did not confirm this hypothesis[31].What can be inferred from the data is that the studied megafauna exhibits pulses in abundance not necessarily linked to the yearly seasons[32]. Patterns of richness, abundance and biomass were not observed in the present data, although the variability in shallow areas was notable[33] and deep zones in the different sampling campaigns exhibited high consistency when using the studied parameters[34-36].

\section{Acknowledgment}

This research has been financed by the SENER-CONACYT Hydrocarbons Project 201441. This is a contribution from the Gulf of Mexico Research Consortium (CIGOM).

\section{References}

1. Smith CR, Hamilton SC (1983) Epibenthic megafauna of a bathyal basin off southern California: patterns of abundance, biomass, and dispersion. Deep Sea Research Part A. Oceanographic Research Papers 30(9): 907-928.

2. Collie JS, Escanero GA, Valentine PC (1997) Effects of bottom fishing on the bethic megafauna of Georges Bank. Marine Ecology Progress Series 155: 159-172.

3. Wei CL, Rowe GT, Fain Hubbard G, Scheltema AH, Wilson GDF, et al. (2010) Bathymetric zonation of deep-sea macrofauna in relation to export of surface phytoplankton production. Marine Ecology Progress Series 399: 1-14.

4. Ramírez EL, Billett DSM (2006) Ecosistemas de las profundidades marinas: reservorio privilegiado de la biodiversidad y desafíos tecnológicos. In: Duarte CM (Ed.), La exploración de la diversidad marina. Desafíos científicos y tecnológicos. Fundación BBVA. Barcelona, España pp. 65-94.

5. Ayma A, Aguzzi J, Canals M, Lastras G, Bahamon N, et al. (2016) Comparison between ROV video and Agassiz trawl methods for sampling deep water fauna of submarine canyons in the Northwestern Mediterranean Sea with observations on behavioural reactions of target species. Deep Sea Research Part I: Oceanographic 114: 149-159.

6. Piepenburg D, Chernova NV, von Dorrien, CF, Gutt J, Neyelov AV, et al. (1996) Megabenthic commmunities in the waters around Svalbard. Polar Biology 16(6): 431-446.

7. Bluhm BA, Iken K, Hardy SM, Sirenko BI, Holladay BA (2009) Community structure of epibenthic megafauna in the Chukchi Sea. Aquatic Biology 7: 269-293.

8. Durden JM, Bett BJ, Jones DOB, Huvenne VAI, Ruhl HA (2015) Abyssal hills - hidden source of increased habitat heterogeneity, benthic megafaunal biomass and diversity in the deep sea. Progress in Oceanography 137: 209-218.

9. Tecchio S, Ramírez-llodra EVA, Sardà F, Joan B Company (2011) Biodiversity of deep-sea demersal megafauna in western and central Mediterranean basins. Scientia Marina 75(2): 341-350.

10. Linse K, Barnes DKA, Enderlein P (2006) Body size and growth of benthic invertebrates along an Antarctic latitudinal gradient. Deep Sea Research Part II: Topical Studies in Oceanography 53(8-10): 921-931.

11. Buhl-Mortensen L, Ellingsen KE, Buhl-Mortensen P, Skaar KL, Gonzalez-Mirelis G (2016) Trawling disturbance on megabenthos and sediment in the Barents Sea: Chronic effects on density, diversity, and composition. ICES Journal of Marine Science 73(1): i98-i114.

12. Kumar RT, Sampson A, Dorathy E, Wokoma I, Adjetey M (2013) Study on Environmental impact on oil and gas activities in Ghana- Analysis by graphical approaches using Matlab. International Journal of Engineering Trends and Technology 4(3): 344-348.

13. Stout SA, Rouhani S, Liu B, Oehrig J, Ricker RW, et al. (2016) Assessing the footprint and volume of oil deposited in deep-sea sediments following the Deepwater Horizon oil spill. Marine Pollution Bulletin 114(1): 327-342.

14. McGuire T (2008) History of the Offshore Oil and Gas Industry in Southern Louisiana, pp. 323.

15. Edgar GJJ, Bustamante RHH, Farina JM, Calvopina M, Martinez C, et al. (2004) Bias in evaluating the effects of marine protected areas: the importance of baseline data for the Galapagos Marine Reserve. Environmental Conservation 31(3): 212-218.

16. Ortiz-Pérez MA, Gudalupe De la Lanza-Espino (2006) Diferenciación del espacio costero de México: un inventario Regional. In: Instituto de Geografía. Fecha de publicación, UNAM, pp. 138

17. Caso M, I Pisanty, Ezcurra E (2004) Diagnóstico Ambiental del Golfo de México. In: México (edn.) Secretaría de Medio ambiente y Recursos Naturales, Instituto Nacional de Ecología. Het Research Institute for Gulf of Mexico Studies, pp. 626

18. Pielou EC (1975) Ecological diversity. In: A Wiley-Inter science publication, New York, USA, pp. 210

19. Magurran A E (1988) Ecological diversity and its measurement. In: Princeton University Press, Princeton, New Jersey, USA pp. 179

20. Pequegnat WE, Gallaway BJ, Pequegnat LH (1990) Aspects of the ecology of the deep-water fauna of the Gulf of Mexico. American Zoologist 30(1): 45-64.

21. Murawski SA, Peebles EB, Gracia A, Tunnell JW, Armenteros M (2018) Comparative abundance, Species composition, and Demographics of Continental Shelf Fish Assemblages throughout the Gulf of Mexico. 
Marine and Coastal Fisheries Dynamics Management and Ecosystem Science 10(3): 325-346.

22. Hernández-Ávila I, E Guerra-Castro, C Bracho, M Rada, FA Ocaña, et al. (2018) Variation in species diversity of deep-water megafauna assemblages in the Caribbean across depth and ecoregions. PLOS ONE 13(8): e0201269.

23. Hill M O (1974) Correspondence analysis: A neglected multivariate method. Applied Statistics 23(3): 340-354.

24. Torruco D (1988) Estructura de la fauna nectobentónica del sublitoral frente a Laguna Verde, Veracruz. In: Tesis Maestría, CINVESTAV U, Mérida, México.

25. Escobar-Briones E (2000) La biodiversidad del mar profundo en México. Biodiversitas 29: 1-6.

26. Flint W, Rabalais N (1981) Environmental studies of a marine ecosystem: South Texas outer Continental Shelf. In: University of Texas Press, Austin, pp. 1-268

27. Terborgh JW, Faaborg J (1980) Saturation of bird communities in the West Indies. The American Society of Naturalists 116(2): 178-195.

28. MacArthur RH (1965) Patterns of species diversity. Biological Reviews 40(4): 510-533.

29. Birchenough SNR, Reiss H, Degraer S, Mieszkowska N, Borja A, et al. (2015) Climate change and marine benthos: a review of existing research and future directions in the North Atlantic. WIREs Clim Chang 6(2): 203-223.
30. Edden AC (1971) A measure of species diversity related to the lognormal distribution of individuals among species. Journal of Experimental Marine Biology and Ecology 6(3): 199-209.

31. Iken K, Brey T, Wand U, Voigt J, Junghans P (2001) Food web structure of the benthic community at the Porcupine Abyssal Plain (NE Atlantic): A stable isotope analysis. Progress in Oceanography 50(1-4): 383-405.

32. Lessard-Pilon SA, Podowski EL, Cordes EE, Fisher CR (2010) Megafauna community composition associated with Lophelia pertusa colonies in the Gulf of Mexico. Deep-Sea Research Part II 57(21-23): 1882-1890.

33. Rowe GT, PT Polloni, SG Horner (1974) Benthic biomass estimates from the northwestern Atlantic Ocean and the northern Gulf of Mexico. Deep Sea Research and Oceanographic Abstracts 21(8): 641-650.

34. Solís-Marín FA, Laguarda-Figueras A, Durán-González A, VázquezBader AR, y Gracia A (2014) Biodiversidad de los equinodermos (Echinodermata) del mar profundo mexicano. La Frontera Final El océano profundo pp. 215-253.

35. Torruco D, E Chávez, González A (2007). Spatio-temporal variation of the structural organization of demersal communities in the southwestern Gulf of Mexico. Rev Biol Trop 55(2): 509-536.

36. Thomas Schlacher, Ashley A Rowden, JF Dower, M Consalvey (2010) Recent advances in seamount ecology: A contribution to the census of marine Life. Marine ecology pp. 244.

\section{Your next submission with Juniper Publishers} will reach you the below assets

- Quality Editorial service

- Swift Peer Review

- Reprints availability

- E-prints Service

- Manuscript Podcast for convenient understanding

- Global attainment for your research

- Manuscript accessibility in different formats (Pdf, E-pub, Full Text, Audio)

- Unceasing customer service

Track the below URL for one-step submission https://juniperpublishers.com/online-submission.php 